\title{
Public parliamentary discourse in Russia and Germany: speech and genre specifics
}

\author{
Anna Konstantinova ${ }^{1}$, Svetlana Anufrienko ${ }^{1, *}$, Asiyat Botasheva ${ }^{1}$, Olga Totskaya $^{2}$, and Natalya Tkacheva $^{2}$ \\ ${ }^{1}$ Department of Conflict Resolution Studies, Public Relations and Journalism, Pyatigorsk State University, 9, Kalinina lane, 357532, \\ Pyatigorsk, Russia \\ ${ }^{2}$ Department of European Languages, Pyatigorsk State University, 9, Kalinina lane, 357532, Pyatigorsk, Russia
}

\begin{abstract}
In the article the approaches to the problem of political discourse speech genres differentiation are discussed based on the comparative analysis of the German and Russian public parliamentary speech authentic samples. The special status of the public speech phenomenon in parliamentary communication and its conditionality by parliamentary regulations are discussed. The communicative roles of plenary sessions' participants in Germany and Russia are described. In both parliaments, public parliamentary speech is exercised in a dialogue form, managed and controlled by the president of the Bundestag / presiding plenary session. The existence of common political goals of German and Russian public parliamentary communication proves the expediency of its comprehensive comparative study, taking into account extralinguistic and linguistic characteristics of public parliamentary speeches. The statements, representing the German and Russian public parliamentary speech, form a set of institutional genres, the emergence and functioning of which are predetermined by the parliamentary regulations. In both parliaments, they include a report, a statement, a question, and a reply, presented in several intragenre varieties, with specific national variants. Each of these genres is characterized by the use of specific methods of language expression, emotional utterances, rhetorical and polemical techniques
\end{abstract}

\section{Introduction}

The political life intensification happening in the society now and its undoubted influence on the forms and means of mass communication provide a keen interest in studying political communication discourse. At the present stage of public relations development an important role in political life is played by the institute of parliament. The parliamentary discourse is an integral component of mass communication in a democratic society. Parliamentary discourse reflects not only the language, but also cultural and historical, ideological, intellectual, social and other types of native speakers' experience. It proves the relevance of a parliamentary discourse problem in general and the relevance of this work performed in the aspect of comparative study of the speech and genre characteristics of German and Russian parliamentary discourse.

Public speech communication between parliamentary discourse participants is exercised in the State Duma of the Russian Federation and the Bundestag of Germany, mainly, in an oral form of a polylogue (dialogue). Its participants produce and reproduce spontaneous text units of severalinstitutionalized speech genres that assume restrictions for the speech of the participants and language means to be used. A. Beard notes that linguistics can and has to bring its contribution to the theory of language "institutionalism" [1].
The existence of the words and expressions designating key concepts of political discourse in the language allows some researchers to use the term "political language" for their designation. In this regard scientists started to use the term "parliament language" considered as a component of "political language". Some researchers determine the communication language in the Bundestag as a layer between a vernacular and national languages [2-4]. As R. Hoberg states, the political language, especially in the parliament, is notable for a property to include language units of all spheres of knowledge, therefore it should have an opportunity to provide parliamentary communication at the expense of both professional communication language and the language of daily communication [5].

It is indisputable that the language plays an important role in parliamentary communication. As J. Searle considers, like other public institutes, the language can also be considered as an institute - in a narrow sense of the word. It is such an institute which, unlike other institutes, cannot be abolished by a resolution [6]. Without the language which is a cornerstone of "organizational rules of a discourse" [7], not only verbal communication in general, but establishment of modern public institutes is inconceivable.

According to J. Charteris-Black, for designation of the language of public parliamentary communication we can accept the term "parliament language" [8].

\footnotetext{
Corresponding author: ssidorova@list.ru
} 
These approaches are disputable as "political language" in general and "parliament language" in particular include, mainly, a lexicon of national language which is supplemented by a political lexicon. As for the units of other levels of the language system, public parliamentary communication keeps within the language norms.

The above-mentioned fact gives us the grounds to support those authors who claim that in the political discourse mainly official and publicistic styles are used [9-10].

\section{Materials and methods}

The main objective of this research is to compare German and Russian public parliamentary speech according to their speech and genre specifics.

To reach that goal, the following tasks are to be fulfilled:

- to analyse shorthand reports of plenary sessions of the Bundestag (Germany) and the State Duma (the Russian Federation) with respect to their speech and genre specifics;

- to study the main genres of the German and Russian public parliamentary speech, their composite organization, language means and the purposes of these means use in the speech of different parties and factions representatives;

- to systematize the universal and special in German and Russian public parliamentary communication;

- to reveal the perspectives of the parliamentary genres study.

In a row of various speech events taking place in the parliamentary discourse, the study of communication in the sphere of public policy is of particular interest. As for the meetings of the committees and factions, a linguist does not have a direct access to observe the communication that takes place there. The communication that takes place on the sidelines of the parliament is not public by definition. The presentation of the content of political communication in the press is a product of mediatization, an interpretation of the actual content of the message, in which the society, the authorities and the media are interested. Therefore, it is possible to observe parliamentary communication in the most "pure" form in the public parliamentary speech, recorded in transcripts.

In the course of the work, the public statements of the Bundestag deputies of the Federal Republic of Germany (https://www.bundestag.de/protokolle) and the State Duma deputies of the Russian Federation (http://duma.gov.ru/legislative/transcripts/), recorded in the transcripts of the plenary sessions in 2004-2018 (more than 3000 examples) were analyzed and compared. We applied the methods and techniques of political linguistics, functional stylistics and pragmalinguistics, corpus linguistics (to identify typical contexts), as well as a number of particular linguistic methods and techniques: interlanguage comparison and description of information tools and impact, methods of distributional analysis and logical-semantic interpretation.

\section{Results and discussion}

In the late 20-th century the speech genres were studied by scientists from the viewpoint of text theory [11-12]. In the theory of speech genres, which is oriented on modern text typology, speech genres are seen as a brief list to illustrate each type of the text [13-15].

Genres can be interpreted as conceptual entities that have a prototype value-cultural nature, and as ethnoculturally determined models of speech behavior and social practices of participants in a discourse. Recently, scientists have made a number of attempts to classify speech genres on the basis of a systemic examination of a speech act model. Thus, the classification of speech genres and the types of text representing them, proposed by the German researcher R. Eckard, is of particular interest. Under a text type, R. Eckard understands a cumulative illocutionary property of a certain corpus of speech genres [16]. Following the principles of this classification, in the parliamentary discourse one can find the characteristic features of transmitting, announcing, determining subject parameters of decisions made, admitting, representing, recording, passing judgments, polemical, binding, stabilizing, destabilizing and index speech genres.

The text typology development marked the beginning of the speech genres study, one of the tasks of which was to reduce the whole diversity of texts to a certain number of text types - by identifying the specific features inherent in each of them. From the communicative point of view, the compositional-speech forms inherent in them function in different discourses. On the one hand, they draw up statements and text fragments and implement the compositional characteristics of the connected texts; on the other hand, they act as complex syntactic formations that obey the laws of the language units' organization.

The text composition of the public parliamentary discourse differs from the texts of other discourses for it is set in advance - in the approved agenda. But it can be changed when new questions arise and subjects of speech replace each other.

The compositional organization of the parliamentary discourse genres has both universal features and its own characteristics, which consist of the actual ratio of their content and the textual units representing them, belonging to different genres and compositional speech forms and covering all aspects of the semantically significant structure of the speech. The compositional speech forms of the public parliamentary discourse depend on the content and objectives of the speech activities of its participants. Some highlight the results of work on bills, others express the views of their party and oppose in favor of or against one or another point of view expressed by other participant / participants in the discourse. These speech actions are determined by the roles of the speakers (co-rapporteurs), the audience, the presidium, the presiding person, who regulates the order 
of speeches from the podium and monitor their compliance with the rules.

Also from the viewpoint of the genre features of the public parliamentary speech, the problem of its authorship is of interest, whether the text of the report / speech is created by one or several authors. As the study showed, in both parliaments the texts of parliamentary communication are characterized by the following features:

- dialogic (polylogical): the content is jointly formed and explicated by several participants-authorizers;

- polyglossia: authorizing subjects constantly change, which affects how and in what light the events are given and how their composition is formed, i.e. it affects the form of expression and content.

From the viewpoint of speech pragmatics, it is of interest to study the preferences given by the speech subjects to certain language means and ways of expression, which makes it possible to consider texts in the aspect of represented speech strategies and tactics. Studies of role repertoires, within which parliamentarians act when communicating with different recipients, have led to the conclusion that in both parliaments there is a tendency that a special role of "expert deputies" emerges, which shows independence from both the formation of positions and their representations at the language level [17]. The abovementioned tendency can be attributed to the public speech activity in the State Duma of the Russian Federation and the Bundestag of the Federal Republic of Germany of such deputies as Zhirinovsky, Mitrofanov, Fisher, Brandt and several others.

In different historical periods of the public institutions existence, certain functional and stylistic features of the language are manifested in the speech of the participants. So, for example, in the 19th century in Germany, deputies who sought to create the image of a trustworthy official familiar with the legal subtleties used certain "markers of dignity" to address the plenary: Hohes Gericht!, Hochwürden!, Magnifizienz!, Verehrte Ageordnete!, Meine Damen und Herren!, Onorevole! (High Court!, Highly Esteemed Members of the Court!, Your Excellency!, Honorable Members!, Ladies and Gentlemen!, Onorevole! These markers are characteristic of formal business communication in general. Those deputies who, on the contrary, tried to get closer to their audience, whether they were MPs or the public, used a less formal or conversational style. This trend can be observed in the 20th and 21 st century.

Verbal communication in parliamentary discourse is sometimes figuratively defined as "patterned". This definition means that in the speech actions of each of the participants, the "institutional voice", assigned to them by their status and communicative role, is realized. To consider the public speech produced in the parliament as "stereotyped", i.e. characteristic of this discourse due to its institutional nature, let us think about the fact that the text types and speech actions nomenclature is implemented in the parliamentary discourse fairly wide. The implementation of the "institutional voice" of a parliament member is carried out by performing "stereotyped" speech actions, prescribed by the regulations and the procedure to be followed.

The genre structure of political discourse can be represented as a field structure, which includes several genres and genre variations inherent in political communication. In the center of this field there are those genres that most closely correspond to the main purpose of political communication - the struggle for power. These include parliamentary hearings, debates, preelection speeches by politicians, official information about the state activities of the parliament, the president and the government, published in the media. The periphery includes genres in which the function of the struggle for power is closely intertwined with the functions of other discourses. The space between the periphery of the field and the central genres of political discourse can be represented by the genres of media discourse of political content.

An important feature of political discourse is that this type of institutional discourse intersects with a great number of others. In particular, political discourse intersects with a pedagogical one. The specificity of this intersection is in the two-dimensional mode - formal and informal political education, carried out through public educational institutions, through the influence of the media and in everyday life. In the sphere of state legislation the political discourse overlaps the legal one. The intersection of political and religious discourse, according to E. Shaygal, arises in the sphere of mythologization of consciousness, belief in the magic of words, recognition of the divine role of a leader, use of manipulation methods and ritualization of communication [18]. Political discourse also borders on a sports game; a fierce struggle for power is played out as a contest, as big national games for which entertainment is important, certain images, forms of manifestation of speech aggression, etc. The relations between the central and peripheral genres of political discourse can also be represented as a scale on which they are ordered according to the degree of reduction of political discourse signs and the increase in the number of signs of other discourses (both institutional and personal).

Patterned speech genres of political discourse can be modified. In such cases, for example, the structure of a political report has common features with a scientific report that includes a rationale for the topic; showing different aspects of the topic; posing problems; description of possible solutions; arguing the choice of these solutions; a detailed list of the conditions for carrying out certain actions. However, a political report as a monologue message preserves a number of significant differences from the monological genre of a scientific report: in both structural and content differences.

In the parliamentary discourse, as a kind of political discourse, researchers note both institutional and transposed signs, i.e. signs of other discourse types that manifest themselves as such (for example, elements of preaching as a genre of religious discourse found in the speech of a parliament member). Such genres are sometimes referred to as hybrid, or syncretic ones. 
Speech genres of public parliamentary discourse can be viewed as various forms of expedient presentation of factual and conceptual content. In public parliamentary discourse as a special kind of political discourse, one can find a number of "stereotyped" genres and signs of combining or merging different genres, such as a report, a political document (legislative language, normative acts, etc.), informational and discussion speeches.

There are disagreements regarding the number of genres of parliamentary discourse and their constituent features. Most researchers refer report, speech, question and reply to the main genres of the Russian and German parliamentary speech. Some single out information, an official deputy inquiry, an intermediate question (a big and small question in the Bundestag) and a discussion speech as special parliamentary genres.

If we take the functional-semantic principle as a basis for the genre division of the parliamentary discourse, then the genres of political discourse can be divided into informational, argumentative-analytical and imperative. The speech of a responsible person before the parliamentary audience with a report, analysis of current events, and information on domestic and international politics is reflected in such an informative genre of monologue speech as a report. In a monologue speech of an informational nature, characteristic of a parliamentary report (co-report or message), the tendency towards a descriptive-narrative development of the topic (narrative in the broad sense of the word) prevails.

A speech is a monologue of a politician dedicated to the discussion of a report. Since a speech usually contains elements of controversy, it does not seem quite reasonable to single out a discussion speech as a special genre.

A reply is a brief, usually emotionally colored objection in a dialogue, a remark, a comment relating to the assessment of the content of the previous speaker's speech. Unlike reports and speeches, which are usually planned in advance, are put on the agenda and are pronounced from the podium or from the floor according to a pre-approved text, a reply is a spontaneous statement from the floor, usually with its expressive polemical strategies and tactics. The authors of the replies can be both deputies speaking from the floor, and (quite seldom) - members of the presidium - those who regulate the course of the meeting.

For communicators of the German and Russian parliaments, as for mass communication as a whole, it is common to shout from places or accompany their speech from the podium with shouts. So, for the members of the German parliament, the exclamations "Hört! Hört!", "Sehr wahr!" ("Listen! Listen!", "Very true!") are typical. The question arises about their genre affiliation. Such shouts from the seats, as well as statements of universally recognized genres, are an integral part of parliamentary meetings. In the Bundestag, shouts are recorded by transcribers. This gives grounds for some researchers to consider them, along with remarks, which are also spontaneous expressive utterances, as a special genre of parliamentary speech. In the State Duma of the Russian Federation, the shouts from places in the transcripts are not fixed (instead, the standard formula "shouts, noise in the hall" is used).

At present, the influence that replies and shouts have on parliament discourse has not been studied enough. In particular, a noteworthy fact is that, unlike other genres of parliament discourse, replies, like questions, are selforganizing text units, the appearance of which in the parliament speech is not predetermined and not prohibited by precedent text.

If we talk about shouts from places as a means of expressing agreement / disagreement with a speaker, they are most closely associated with the non-verbal behavior of the participants in the discussions. So, specifically parliamentary non-verbal means of emotional expression of disagreement with what is happening can be called a knock on the console lid or a demonstrative exit from the conference room by a person or a group of people.

A question is a specific regulated genre, an interim question especially characteristic of parliamentary discussions. When making it, certain rules must be consistently followed. The discourse of the Duma of the Russian Federation highlights the official deputy inquiry, which has a written form. In the Bundestag, it is customary to distinguish between large and small inquiries. This genre is realized, above all, by institutionalized speech actions of the inquiry.

A big inquiry is usually larger than a small one; it may appear during an oral debate, but requires a detailed written response. A big inquiry contains questions that are usually formulated by the opposition party and sent to the government. Sometimes the ruling party makes such an inquiry to the ministers who are members of their own party, in order for them to report on the intentions or successes of the government in an expanded form.

Big inquiries to the government in accordance with paragraph 100 , clause 1 of the regulations of the Bundestag must be formulated correctly and concisely, can be provided with a brief justification and are passed directly to the President of the Bundestag. The president requires the government to report the time of the response to the inquiry. According to the regulations, a response must be received within six weeks. In practice, the answer, as a rule, can only be obtained within a few months. A big inquiry must be signed by at least $5 \%$ of deputies (either by a closed deputy group, which does not necessarily have to be $5 \%$ of deputies) or may be submitted by the council of elders and serves as the opposition's instrument of political control over government activities.

A small inquiry is a question, consisting of several points, to the representatives of the executive power. This may be, for example, the question of the deputy to the government. A small inquiry is a tool of parliamentary control. The government gives an answer to it usually after a few weeks. At the same time, as a rule, there is no need to conduct any serious investigations (studies). Responses to small inquiries are based on the facts that the government currently has.

Small inquiries are more a tool of the parliamentary opposition. In addition, in this way the opposition can 
express the private interests of its electorate. It most often occurs for the sake of holding subsequent election campaigns.

The next genre used in the parliamentary discourse is a discussion. Discussion speeches are usually produced by the deputies who speak from the parliamentary rostrum both on their own behalf and on behalf of the Committees and factions. The goal of the discussion, which is being implemented openly, is the search for consensus, the only correct solution, or a solution acceptable to the majority of participants. But at the same time, since the task of jointly clarifying some issue is posed in the parliament, this is the search for the truth. Therefore, in the parliamentary discussion, informational and evidence-based arguments are paramount. Parliamentary discussions usually characterize a variety of ways to exert a speech. Participants of the discussion interaction, realizing their goals, use a clear and hidden impact on their opponents. As V. Karasik, notes, one of the hidden goals of the discussion may be to discredit an enemy in the eyes of the audience and to assert his own positions [19]. The latent effect produced is manipulative in nature.

The implementation of the objectives of the parliamentary discussion can be carried out in different verbal-non-verbal forms. By the definition of $\mathrm{A}$. Musolff, the text of a discussion speech is a holistic and complete work, a system that forms an argumentative subtype of analyzing type texts [20]. On this basis, the texts of parliamentary discussions are referred to as stereotyped by their constitutive features. However, this does not exclude the possibility of spontaneous statements from debatable places (replies) of the participants in the discussion. A dialogue (polylogue) is recognized as the main form of the discussion speech. According to R. Boatright, T.J. Shaffer, S. Sobieraj, without a dialogue, which is based on the inherent stability of the democratic consensus and which leads to parliamentary decisions made by the majority, parliamentary democracy will degenerate to a regulatory mechanism [21].

The main public form of searching for and justifying the truth, defending one's own positions and positions of a faction, as well as critics and accusations of the opposition have all the qualities inherent in the dialogue and present at the plenary session of the parliament. The composition of the participants of the plenary meetings is characterized by the composition of the constant change of the roles of the sender and the addressee. Those who present in the meeting room of the parliament: speakers - from the rostrum and the rest of the deputies - from their seats can spontaneously address the speakers and the presidium.

The difference in the degree of spontaneity of verbal/non-verbal communication between participants in a situation of public parliamentary communication is noted, in particular, in the fact that the shouts of deputies from places familiar to the general atmosphere of Bundestag meetings in the Duma are suppressed. In the case of such a violation of the rules, the microphone is turned off, and the reply / exclamation itself is not fixed in the transcript.
Comparison of the main genres of public speech in the State Duma of the Russian Federation and the German Bundestag showed the following.

Reports submitted to the plenary meetings, in both cases, have a written basis; their content is discussed in advance and undergoes prior coordination at the meetings of committees and factions. Both German- and Russian-language reports are mostly informative and correspond to the standard of official business narrative.

As the examples show, the speech of the rapporteurs and co-rapporteurs in their form and content is most consistent with the idea of parliamentary regulations, norm / standard. It is an oral reproduction of the written text, designed for its oral delivery in the time interval allotted by the regulations, built on a clear plan, contains mainly subject-logical information and is emotionally neutral.

In contrast to reports, speeches from the podium during the discussion of draft laws have primarily the character of argumentative and analytical discussion.

The texts of speeches from the podium draw attention as they have a clear logical and semantic basis, and contain inferences and arguments, for example:

"Sagen wir einmal, die Zinsen sinken in den schwachen Ländern um 2 Prozent und steigen bei uns um 2 Prozent. Habt ihr, liebe Grüne, eigentlich einmal ausgerechnet, was ein Anstieg der Zinsen um 2 Prozentpunkte für den Bundeshaushalt bedeuten würde? - 25 Milliarden Euro Mehrausgaben. Das ist der Wunsch von Grünen und SPD, wenn sie einen Altschuldentilgungsfonds fordern, der hier die Zinsen und damit die Steuerlast erhöhen würde.

(Beifall bei Abgeordneten der FDP und der CDU/CSU - Sven-Christian Kindler [BÜNDNIS 90/DIE GRÜNEN]: Welche Berechnungen gibt es denn dazu? Das ist doch totaler Quatsch!)" (Let's assume that interest falls by 2 points in fragile states and grows by $2 \%$ in our country. Have you actually calculated, dear members of the Green Party, what means a 2 percent increase in the interest for the federal budget? - It means 25 billion euros of additional costs. This is the desire of the members of the Green Party and the SDP to require a fund to eliminate old debts. It would increase the interest but, at the same time, the tax burden.

Approval from the deputies of the FDP and the CDU / CSU - Sven-Christian Kindler [UNION 90 / MEMBERS OF THE "GREEN" PARTY]: What calculations are there about this? That's total nonsense!).

“Вот вы сказали, что Правовое управление не имеет замечаний. Но тут написано: «Вместе с тем отмечаем, что в подпункте «а» статьи 20 Соглашения после слова «иммунитет» перед словами «юрисдикиии ...» пропущен предлог «от». Я специально изучаю все эти вопросы, и если вы внимательно посмотрите, то поймёте, что $u$ Правовое управление неправильно это трактует. «Oт юрисдикиии судебньх ...» - если вы «от» пропустили, то получается совершенно другой смысл статьи. Почему вы не учитываете вот эти замечания? Ну, это же будет совсем другая статья: вы лишаете иммунитета людей, которые будут заниматься этой деятельностью. Неужели 
замминистра и вы не понимаете этого?" ("So уои said that the Legal Department had no comments. But it says here: "At the same time, we note that in the subparagraph " $a$ " of Article 20 of the Agreement, after the word "immunity", before the word jurisdiction ..." the preposition "from" is omitted. I study all these issues, and if you look carefully, you will understand that the Legal Department also interprets this incorrectly. "From the jurisdiction of the courts ..." - if you miss "from", then you get a completely different meaning of the article. Why do not you take these comments into account? Well, this will be a completely different article: you are depriving immunity of people who will be engaged in this activity. Don't you and the deputy minister understand this?").

The remarks and intermediate questions of the participants of the parliamentary sessions are spontaneously generated. In these spontaneously produced textual units, the intention is to effectively and aggressively influence listeners [22]. For this purpose, various means of intensification are used: modal and evaluative words, tropes, stylistic figures, rhetorical devices. In these genres, not informative, but influencing function, which is realized by means of statements of argumentative-analytical, argumentative and purely emotional character, prevails:

"Глубокоуважаемый Николай Васильевич, уверен, что вы, как и все присутствующие в этом зале, более чем хорошо владеете русским языком, но вместе с тем ни вы, ни члены комитета не являетесь экспертами по данному вопросу. Поэтому я предлагаю вам обратиться в Институт русского языка для получения заключения на ваше предложение. Спасибо". ("Dear Nikolai Vasilievich, I am sure that you, like everyone else in this room, are more than fluent in the Russian language, but at the same time, neither you nor the committee members are experts on this issue. Therefore, I suggest you contact the Institute of the Russian Language for an opinion on your proposal. Thank you. “).

„Frau Kollegin Reiche, vielen Dank für die Informationen, die uns bekannt sind. Da Sie auf meine Frage, welche wissenschaftliche Basis diese Beschlüsse haben, nicht eingegangen sind, nehme ich nun zur Kenntnis, dass es offensichtlich keine wissenschaftliche Basis gibt". (Frau Reiche, thank you for the information we know. Since you have not answered my question about the scientific basis for these decisions, now I note that obviously there is no scientific basis).

In the above examples, you can note the features of the publicistic style. Exclamations, imperatives, formed with the help of imperative forms of the verb, explicit expressions bring these genres closer to emotive everyday conversation, and sometimes to belles-lettres style. This type of speech characterizes categorical, strong critical beginning, and often peremptory judgments. Interestingly, the most frequently used trope in discussion speeches is a hyperbole, for example:

„, Wenn ich die Reden der Opposition höre, habe ich das Gefühl, dass sie sich gar nicht bewusst darüber ist, was für eine Verantwortung dieses Parlament für Europa in den nächsten Wochen hat und welche Verantwortung es bereits heute mit diesem Nachtragshaushalt wahrnimmt". (When I hear the speeches of the opposition, I have a feeling that they are unaware of the responsibility that this Parliament will have for Europe in the coming weeks and what responsibility it already has with this supplementary budget).

The speech activity of the chairperson (the president of the parliament or the elder in the Bundestag), who controls the course of the meeting, is not usually a wellstudied area of the parliamentary discourse. Unlike the behavior of other participants in the meetings of the Bundestag, this speech behavior is most concise, most institutionalized, i.e. subordinated to the regulations and, as a rule, emotionally neutral and non-expressive. In the State Duma of the Russian Federation, the chairperson can use emotionally colored appeals and imperative sentences, for example:

“Вопросы есть докладчику? Ecть. А чего же Рябов-то не поднимает руку? Коломейщев, Селезнёв есть, а Рябов не поднимает. Вот удивительно!” ("Are there any questions to the speaker? Yes, there are. But why isn't Ryabov raising his hand? Kolomeytsev, Seleznev are, but Ryabov is not. That's amazing! ").

The behavior of the chairman of the State Duma meeting, which goes beyond the framework of the regulations, can be directly assessed by the audience, for example:

“... ну, некорректна ваша постановка вопроса: поднимают те, кто читает, а те, кто не читает, y них вопросов никогда и не бывает”.(“... well, your statement of the question is incorrect: those who read, they raise their hands, and those who do not read, they never have questions.").

But if the presiding person at the meetings of the Duma of the Russian Federation sometimes can deviate from the verbal behavior prescribed by the regulations, we have not noted such cases of non-standard verbal behavior of the Bundestag President or the elder who controls the discussion.

\section{Conclusion}

A parliament as one of the democratic public institutions is represented by groups of people who fulfill institutional roles, prescribed by the rules of communication. The parliament discourse can be viewed as a social institution of a single country and as a global phenomenon in the political life of different countries, conditioned by the society's democratization. From the viewpoint of political linguistics, a factor uniting the parliament discourse with the concept of being an instrument of political power of individual countries may be that parliament discourse in any country is both a means of communication and the objective of its participants.

In the target communication, the main reference point is the achievement of a goal which, in relation to the used verbal-non-verbal signs and symbols, is external. It consists in concluding, through a chain of formal and informal consultations, coordinating positions and consents, such an agreement in the society 
with an excessive amount of social problems. The agreement, aimed at the further social development of this society, will allow conveying a message from the civil society structures to the government and backwards.

Summarizing the study, we can draw the following main conclusions:

1. Public parliamentary communication in both compared parliaments - the Bundestag of the Federal Republic of Germany and the State Duma of the Russian Federation - is characterized by the predominant use of the dialogical form of speech. Most of the statements produced in the main genres of public parliamentary speech - in reports, information and analytical speeches, discussions, questions and replies are sustained in the literary and conversational style. There is a prevalence of standardized, emotionally neutral words and expressions used by the majority of participants in the parliamentary discourse that is up to $70 \%$ of the entire corpus of the analyzed texts. Slightly more than $30 \%$ are the statements containing a certain number of emotionally colored and figurative units, as well as vocabulary related to the spoken and subnormal language layers. In the genres of discussion and replies, the use of invectives can also be noted and can be attributed to the peculiarities of the speech behavior of individual speakers.

2. Language means of expression in public parliamentary speech can be used to designate ideologies, to demonstrate social superiority, social equality, social proximity or social inequality. By means of emotionally colored vocabulary, emphatic grammatical constructions, tropes and stylistic figures, the ideological positions of speakers are represented, social statuses are demonstrated, the distance is marked, and the significance of the discussed issues is explicated. The use of political language units in the speech of representatives of different parties and factions makes it possible to reconstruct the core of public parliament discourse not only as emotionally marked, but as ideologically marked and on this basis to characterize the genres of public parliamentary speech: a report, a speech, a question and a reply as ideological.

The comparison of German and Russian examples corroborated that these characteristics of public parliament speech are universal, i.e. they are not accidental, but they are manifestations of the general patterns of the thought-speech activity organization in the political discourse.

In both parliaments, the texts of parliamentary communication are characterized by polylogy (dialogue) and polyglossia.

3. Addressing in German public speech is more specific than in Russian. In the Bundestag, the speech actions of the participants in the plenary sessions are also more clearly regulated than in the State Duma of the Russian Federation (the difference is no more than 3\%). The regulation of parliamentary speech by the procedures of public communication in both cases is expressed in the priority of the official business style; in some materials there is a combination of official business and publicistic styles; in even rarer cases, signs of belles-lettres and literary style texts predominate. At the same time, our observation makes it possible to note that in parliamentary public speech both German and Russian native speakers do not use any special "parliamentary", "political" or "sublingual" language, as some Russian and foreign researchers claim, but one of the variants of national literary language. The universal features of a public parliamentary speech include the fact that it is implemented in the genres of the report, speech, question and reply, due to the general communication goal of the parliament as a social institution, the procedure rules for the plenary session and the standard forms of communication exchange. Individualizing features are the features of parliamentary rituals and national speech etiquette, as well as systemic and structural features of the German and Russian languages. The choice of evaluative means of communication in both parliaments is determined by their participants' worldview, ethnic-national value systems, the systems of ideological, spiritual and cultural values of other nations, shared by them or alien to them.

4. Replies or shouts from the floor can be considered as a specific genre of communication within the parliaments, which can be accompanied by a speech from the podium. This type of communication, as well as universally recognized genres, is an integral part of parliamentary meetings. In the Bundestag, their content is recorded by transcribers; in the State Duma of the Russian Federation the content of the shouts from places is not fixed in the transcripts. At present, the influence that replies and shouts have on the parliamentary discourse has not been studied enough and seems to be a promising and interesting area for the study of parliamentary communication. In addition, the speech actions of the chairman (the president of parliament or the elder in the Bundestag) deserve some special attention, as their speech behavior is most succinctly institutionalized, emotionally neutral and nonexpressive, as a rule. But if the presiding person at the meetings of the Duma of the Russian Federation sometimes can deviate from the verbal behavior prescribed by the regulations, still we have not noted such cases of non-standard verbal behavior of the Bundestag President or the elder who controls the discussion.

\section{References}

1. A. Beard, The language of politics (Routledge, London, 1999)

2. D. Abadi, Negotiating group identities in multicultural Germany: The role of mainstream media, discourse relations, and political alliances (Lexington Books, Lanham, 2017)

3. H. Mullen, F. Moten, M. Parker, and M. Onli, Speech acts (Institute of Contemporary Art at University of Pennsylvania, Philadelphia, 2018)

4. D. Vanderveken, Meaning and speech acts (Cambridge University Press, Cambridge, 2009)

5. R. Hoberg, Politischer Wortschatz zwischen 
Fachsprachen und Gemeinsprache Sprache zwischen Militär und Frieden (Narr, Tübingen, 1988)

6. J.R. Searle, F. Kiefer, M. Bierwisch, Speech act theory and pragmatics (Springer, Berlin, 1980)

7. F. Mulle, What is a speech act? A brief introduction to Searle's theory on speech acts (Grin Verlag, München, 2016)

8. J. Charteris-Black, Analysing political speeches: rhetoric, discourse and metaphor (Red Globe Press, Cambridge, 2018)

9. N. Chomsky, Language and politics (AK Press, Chico, 2004)

10. R. Wodak, B. Forchtner, The Routledge handbook of language and politics (Routledge, London, 2017)

11. D. Douglas, Computers and the humanities, The multi-dimensional approach to linguistic analyses of genre variation: An overview of methodology and findings, 26(5-6), 331-345 (1992)

12. M. Shapiro, Language and political understanding (Yale Univ Pr, West Hanover, 1981)

13. S.L. Tsohatzidis, Foundations of speech act theory: philosophical and linguistic perspectives (Routledge, Abingdon, 2002)

14. G. Grewendorf, G. Meggle, Speech acts, mind, and social reality: discussions with John $R$. Searle (Springer, Berlin, 2002)

15. M. Kissine, From utterances to speech acts (Cambridge University Press, Cambridge, 2013)

16. R. Eckard, Die Funktionen der Gebrauchstextsorten (de Gruyter, Berlin, 1993)

17. Th. Luckmann, Soziologie der Sprache (Enke, Stuttgart, 1969)

18. E. Sheigal, The semiotics of political discourse (Peremena, Volgograd, 2000)

19. V. Karasik, Discourse manifestation of personality, Russ. J. of Linguistics 20, 56-77 (2016)

20. A. Musolff, Political metaphor analysis: discourse and scenarios (Bloomsbury Academic, London, 2016)

21. R.G. Boatright, T.J. Shaffer, S. Sobieraj, and D. Goldthwaite Young, A crisis of civility?: political discourse and its discontents (Oxford University Press, Oxford, 2019)

22. M. Temmerman, R. Moernaut, R. Coesemans, and J. Mast, , Discourse, Context and Media, Post-truth and the political: Constructions and distortions in representing political facts 27, 1-6 (2019) 